\title{
THE EFFECTS OF SPECIFIC ORAL NUTRITIONAL SUPPLEMENTS COMPARED TO TEA WITH SUGAR ON GASTRIC EMPTYING TIME, BLOOD GLUCOSE LEVEL, AND HUNGER RESPONSE IN HEALTHY
}

\section{ADULTS}

\author{
$\dagger$ Stella E Bella, ${ }^{1}$ Luciana B Sutanto, ${ }^{1}$ Jacob Pandelaki ${ }^{2}$ \\ 1 Indonesian Nutrition Association, Jakarta, Indonesia \\ 2 Dept. of Diagnostic Radiology, Faculty of Medicine Universitas Indonesia, Cipto Mangunkusumo Hospital \\ Jakarta, Indonesia
}

Abstract-Introduction: The objective of this study was to compare gastric emptying time, hunger response, and blood glucose level after drinking specific oral nutritional supplements (S-ONS) to tea with sugar in healthy adults.

Methods: This study was a clinical, parallel, random allocation, and single-blind trial. This study was conducted at Cipto Mangunkusumo General Hospital, Jakarta. The subjects were 12 healthy adults divided into 2 groups: intervention group (n $=6)$ and control group $(\mathrm{n}=6)$. Patients in the intervention group received $200 \mathrm{~mL}$ S-ONS (200 kcal, $18 \%$ protein, $20 \%$ fat and $62 \%$ carbohydrate) and control group received $200 \mathrm{~mL}$ of tea with 10 grams of sugar $(40 \mathrm{kcal})$. Gastric volume was measured using 2D-sonography every 30 minutes. Blood glucose level was measured using blood peripheral sample. Hunger response was measured using visual analog scale (VAS).

Results: Gastric emptying time in the intervention group was $<90$ minutes, and in the control group $<60$ minutes. Blood glucose level was increased in the intervention group and decreased in control group. Hunger response was decreased in intervention group and increased in control group.

Conclusion: Gastric emptying time after either drinking S-ONS and drinking tea with sugar in healthy adults subjects were less than 2 hours. Patients receiving S-ONS had significantly higher blood glucose level and were less hungry than the control group.

Keywords: ONS, gastric emptying time, bloodglucose level, hunger response

\section{INTRODUCTION}

Fasting before medical procedures, such as elective surgery, abdominal ultrasound scanning, endoscopy scanning, and intubation, is standard protocol to ensure that the stomach is empty and avoid pulmonary aspiration. ${ }^{1}$ Preoperative guidelines state that the minimum duration for fasting before surgery is two hours for clear fluids and six hours for light meal. ${ }^{2-4}$ The guidelines do not include the provision of oral nutritional supplements (ONS), which is more complete in nutritional content, able to meet nutritional needs, and able to reduce hunger as well as maintain blood glucose level. ${ }^{5}$ The stress of surgery may be tolerated by children when they are fed up to $2 \mathrm{~h}$ before elective surgery. ${ }^{6}$ A case report by Sutanto et $a l, 2009^{7}$ concluded that the preoperative nutrition management of patient with ONS resulted in more satisfaction, less hunger, less thirst, and reduced postoperative nausea and vomiting compared to the patient not receiving ONS during the preoperative period.

Oral nutritional supplement could be used as a nutritional choice in preoperative fasting guidelines, therefore the gastric emptying rate after drinking ONS needs to be determined. Research on gastric emptying rate after drinking $200 \mathrm{~mL}$ of specific ONS (S-ONS) with a formula was initiated by Sutanto et al in $2010 .^{5}$ They found that the gastric emptying rate after drinking $200 \mathrm{~mL}$ of S-ONS with a specific formula was less than two hours. The purpose of this study was to compare the rate of gastric emptying, hunger, and blood glucose levels after consuming either S-ONS and tea with sugar.

\section{METHODS}

The study design was a clinical, parallel, random allocation, and single-blind trial. Data was collected in Cipto Mangunkusumo General Hospital, Jakarta, from May - June 2011 after the proposal was approved by the Ethical Clearance Research Committee of Faculty of Medicine University of Indonesia. 
The target population was healthy adult patients and the subjects were those who met the study criteria. Inclusion criteria were 19-50 years old and agreed to join the study by signing the informed consent. Exclusion criteria were patients with nausea and vomiting, or on antiemetic and/or promotility drugs, with high blood pressure and/or diabetes, pregnancy and lactation.

Twelve healthy subjects were allocated by block randomization into two groups, intervention and control groups. The intervention group received $200 \mathrm{~mL}$ S-ONS (200 kcal, 18\% protein, $20 \%$ fat, and $62 \%$ carbohydrate) and the control group received $200 \mathrm{~mL}$ of tea with 10 grams of sugar (40 kcal). Gastric emptying of subjects in both groups were measured using a 2D-ultrasound. This technique has been used, ${ }^{7}$ validated and recommended for gastric emptying assessment. ${ }^{8}$ Gastric volume was determined by using $\pi \mathrm{r} 2 \mathrm{~L}$ formula, the same method used in a study by Sutanto et $a l^{7}{ }^{7}$ To ascertain the stomach was empty before measurement, subjects were required to follow the fasting guidelines, ate last main meal six hours before and drink clear fluid two hours before examination. ${ }^{3}$ The initial examination was considered as empty stomach if the gastric volume was less than $80 \mathrm{~mL} .{ }^{11}$ Measurement of the gastric volume was done every 30 minutes until the stomach was considered to be empty again.

Blood glucose level was measured at the initial and end when measuring gastric volume. Blood sample was taken from peripheral vein. Hunger response was taken at the same time as blood glucose measurement, using visual analog scale (VAS) 0-100 mm interview.

\section{RESULTS}

Both groups had no significant differences in characteristics, as seen in Table 1. The gastric volume was measured using 2D-sonography every 30 minutes, gastric emptying time of intervention group was $<90$ minutes, and control group was $<60$ minutes, therefore gastric emptying time for both groups were less than 2 hours, as seen in Table 2 .

Blood glucose level of the intervention group was increased, while control group was decreased. Subjects received S-ONS had significantly higher blood glucose level than control group, as shown in Table 3.

Hunger response in the intervention group was decreased, while control group was increased. Subjects received S-ONS were significantly less hungry than control group, as shown in Table 4.

\section{DISCUSSION}

The gastric emptying time of all subject were less than two hours; gastric emptying time of the intervention group was longer than control group, 90 and 60 minutes respectively. This result was consistent with the study by Sutanto et al, 2010. ${ }^{5}$ Their study used the same amount and characteristics of ONS as this study although the subject was different, i.e. healthy pregnant patients with a gestational age of greater than 37 weeks. It showed that gastric emptying after drinking $200 \mathrm{~mL}$ $\mathrm{S}-\mathrm{ONS}$ in pregnant women were as fast as non pregnant healthy adults.

The higher calories cause longer gastric emptying time. A study by Gentilcore et al, $2006^{14}$ showed that gastric emptying rate was lower in patients after having higher calories. In that study, one group consumed $500 \mathrm{~mL}$ beef broth soup (12 $\mathrm{kcal}$ ) and the other group consumed $300 \mathrm{~mL}$ of dextrose $25 \%$ (314 kcal). The results of this study was consistent with Gentilcore ${ }^{14}$ in which gastric emptying time of the intervention group was longer than control, in which the intervention group received $200 \mathrm{kcal} \mathrm{S}-\mathrm{ONS}$ and the control group

Table 1. Characteristics of intervention and control groups.

\begin{tabular}{lcccc}
\hline Variable & $\begin{array}{c}\text { Intervention } \\
(\mathrm{n}=6)\end{array}$ & $\begin{array}{c}\text { Control } \\
(\mathrm{n}=6)\end{array}$ & $p$ & CI 95\% \\
\hline Age (years) & $23.17 \pm 3.82$ & $29.00 \pm 5.66$ & $0.067^{*}$ & $-12.16-1.60$ \\
& & & & \\
$\mathrm{BMI}\left(\mathrm{kg} / \mathrm{m}^{2}\right)$ & $21.75 \pm 1.65$ & $20.83 \pm 1.60$ & $0.351^{*}$ & $-1.17-3.00$ \\
& & & &
\end{tabular}


received $40 \mathrm{kcal}$.

Hunger response was decreased from the

Table 2. Mean initial and end gastric volume, and gastric emptying time

of intervention and control groups

\begin{tabular}{ccccc}
\hline Variable & $\begin{array}{c}\text { Intervention } \\
(\mathrm{n}=6)\end{array}$ & $\begin{array}{c}\text { Control } \\
(\mathrm{n}=6)\end{array}$ & $p$ & $\mathrm{CI} 95 \%$ \\
\hline $\begin{array}{l}\text { Initial gastric } \\
\text { volume }(\mathrm{mL})\end{array}$ & $34.67 \pm 15.68$ & $51.33 \pm 12.51$ & $0.071^{*}$ & $-35.03-1.69$ \\
- & 90 & 60 & & \\
$\begin{array}{l}\text { Gastric } \\
\text { emptying time } \\
\text { (minutes) }\end{array}$ & 90 & & & \\
\hline & & & & \\
$\left({ }^{*} \mathrm{p}<0,05\right.$ significant, unpaired t-test)
\end{tabular}

Table 3. Mean initial and end blood glucose level of intervention and control groups.

\begin{tabular}{lcccc}
\hline Variable & $\begin{array}{c}\text { Intervention } \\
(\mathrm{n}=6)\end{array}$ & $\begin{array}{c}\text { Control } \\
(\mathrm{n}=6)\end{array}$ & $p$ & $\mathrm{CI} 95 \%$ \\
\hline $\begin{array}{l}\text { Initial blood } \\
\text { glucose level } \\
(\mathrm{mg} / \mathrm{dL})\end{array}$ & $82.83 \pm 6.58$ & $88.50 \pm 2.95$ & $0.096^{*}$ & $-12.65-1.31$ \\
$\begin{array}{l}\text { End blood } \\
\text { glucose level } \\
(\mathrm{mg} / \mathrm{dL})\end{array}$ & $98.83 \pm 10.42$ & $86.17 \pm 4.17$ & $0.030^{*}$ & $1.68-23.65$ \\
& & & & \\
\hline${ }^{*} \mathrm{p}<0,05$ significant, unpaired t-test $)$ & & & \\
\hline
\end{tabular}

Table 4. Mean initial and end VAS score of intervention and control groups.

\begin{tabular}{lcccc}
\hline Variable & $\begin{array}{c}\text { Intervention } \\
(\mathrm{n}=6)\end{array}$ & $\begin{array}{c}\text { Control } \\
(\mathrm{n}=6)\end{array}$ & $p$ & CI 95\% \\
\hline - $\begin{array}{l}\text { Initial VAS } \\
\text { score (mm) }\end{array}$ & $68.17 \pm 6,05$ & $66.33 \pm 7,78$ & $0.659^{*}$ & $-7.21-10.87$ \\
& & & & \\
- $\begin{array}{l}\text { End VAS } \\
\text { score (mm) }\end{array}$ & $60.00 \pm 4,33$ & $69.83 \pm 6,18$ & $0.011^{*}$ & $-16.80-(-2.86)$ \\
& & & & \\
\hline ( $\mathrm{p}<0.05$ significant, unpaired t-test $)$ & &
\end{tabular}

The amount of calories had an impact on the subjects' blood glucose level and hunger response. At the end, mean blood glucose level of the intervention group was increased (at minute 90), while control group decreased (at minute 90). Compared to the control group, mean blood glucose level of the intervention group was significantly higher. It meant that S-ONS was better than tea with sugar in controlling blood glucose level in patients who would have medical procedure. basal value in the intervention group, while it was increased in the control group. At the end, hunger response was lower in the control group. Compared to the control group, the intervention group receiving $200 \mathrm{~mL}$ S-ONS had lower hunger response.

Theoretically, the lower blood glucose level will decrease glucose supply for brain metabolism, this will stimulate hunger and increase peristalsis. ${ }^{15}$ The results of this study corresponded to that 
theory, the control group with lower blood glucose level had longer VAS which described higher hunger response.

We concluded that by giving S-ONS before medical procedures would help control blood glucose level and prevent hunger. Specific Oral Nutritional Supplements should be considered as a medical drink prior to a medical procedure that requires preoperative fasting. Furthermore, S-ONS could be given 2 hours before medical procedure because gastric emptying time was less than 2 hours. Further studies should be carried out so that S-ONS can be included in the existed standard protocol.

\section{Conflicts of Interest}

The authors declare no conflict of interest regarding this research.

\section{REFERENCES}

1. Teasel RW, Heitzner J, McRae M. The relationship between aspiration and pneumonia following stroke. Top Stroke Rehab 1999;6:17-30.

2. Practice guidelines for preoperative fasting and the use of pharmacological agents for prevention of pulmonary aspiration: application to healthy patients undergoing elective procedures a report by American Society Anesthesiologist task force on preoperative fasting. In: American Society Anesthesiologist (ASA) 1999; 90:896905.

3. The Canadian Anesthesiologists' Society. In: Guidelines to practice of anesthesia 1999.

4. Perkumpulan Ahli Anestesi dan Terapi Intensif (PERDATIN). In: Standar, Pedoman, Petunjuk Praktek Anestesiologi 2007.

5. Sutanto LB, Surani S, Susworo S, Bardosono S, Aziz MF, Madjid AS. Gastric emptying time in full-term pregnancy after drinking a $200 \mathrm{ml}$ oral nutritional supplement: a pilot study among the Indonesian population; 2012. http://www.philspenonlinejournal.com/POJ 0008.html.

6. Yurtcu M, Gunel E, Sahin TK, Sivrikaya A. Effects of fasting and preoperative feeding in children. World $J$ Gastroenterol 2009; 15(39): 4919-4922.

7. Sutanto LB, Surani S, Prasetyno TOH, Syamsudin E, Sugeng A, Muhidin I. Role of enteral nutrition in preoperative patient. Crit care shock 2009;12:95-9

8. Gilja $\mathrm{OH}$, Lundig J, Hausken T, Gregersen H. Gastric accommodation assessed by ultrasonography. World $J$ Gastroen 2006;12(18): 2825-2829.

9. Hausel J, Nygren J, Lagerkranser M, Hellstrom PM, Hammarqvist F, Almstrom C, Lindh A, Thorell A, Ljungqvist O. A Carbohydrate-Rich Drink Reduces Preoperative Discomfort in Elective Surgery Patients. Anesth Analg 2001; 93: 1344-50.
10. World Health Organization WPR. The Asia Pacific perspective: Redefining obesity and its treatment. Health Communications Australia Pty, 2000

11. Johnson G. Holt Biology: Visualizing Life, 1994

12. Datz FL, Christian PE, Moore J. Gender-Related Differences in Gastric Emptying. J Nucl Med 1987; 28: 1204-1207.

13. Fraga TC, Chiapas, JM, Solis S, Sosa M, Alvarado JB, Hernandez E, Gonzales MH. Gender difference in the gastric emptying measured by magnetogastrography using a semi solid test meal. Acta Gastroen Latinoam 2008; 38: 240-245

14. Gentilcore D, Hausken $\mathrm{T}$, Horowitz $\mathrm{M}$, Jones KL. Measurement of gastric emptying of low-and highnutrient liquids using 3D ultrasonography and scintigraphy in healthy subjects. Neurogastroenterol Motil 2006; 18: 1062-1068.

15. Sherwood L. Human physiology: from cells to systems. 6 ed. Belmont: Thompson Brooks Cole. 2007;16:537-587. 